REVIEW ARTICLE

\title{
Ocular benzalkonium chloride exposure: problems and solutions
}

\author{
Michael H. Goldstein ${ }^{1}$, Fabiana Q. Silva ${ }^{1}$, Nysha Blender ${ }^{1}$, Trung $\operatorname{Tran}^{1}$ and Srilatha Vantipalli ${ }^{1 凶}$
}

(c) The Author(s) 2021

Preservatives in multidose formulations of topical ophthalmic medications are crucial for maintaining sterility but can be toxic to the ocular surface. Benzalkonium chloride (BAK)—used in approximately $70 \%$ of ophthalmic formulations-is well known to cause cytotoxic damage to conjunctival and corneal epithelial cells, resulting in signs and symptoms of ocular surface disease (OSD) including ocular surface staining, increased tear break-up time, and higher OSD symptom scores. These adverse effects are more problematic with chronic exposure, as in lifetime therapy for glaucoma, but can also manifest after exposure as brief as seven days. Multiple strategies are available to minimize or eliminate BAK exposure, among them alternative preservatives, preservative-free formulations including sustained release drug delivery platforms, and non-pharmacological therapies for common eye diseases and conditions. In this paper, we review the cytotoxic and clinical effects of BAK on the ocular surface and discuss existing and emerging options for ocular disease management that can minimize or eliminate BAK exposure.

Eye (2022) 36:361-368; https://doi.org/10.1038/s41433-021-01668-x

\section{PRESERVATIVES USED IN EYE DROPS}

Preservatives serve a critical role in the formulation of topical ophthalmic medications used to treat a wide variety of ocular conditions. Required in multidose formulations by most regulatory bodies since the 1970s [1], their primary role is to provide antimicrobial activity to maintain sterility, thus cost-effectively extending shelf life [2]. Their effects, however, are not limited to infectious microbes-many preservatives can also cause significant damage to ocular tissues, particularly in the setting of chronic exposure.

Many different molecules have antimicrobial properties and have been incorporated into ophthalmic formulations. These have been extensively reviewed [2-7] and are summarized in Table 1. Of these, benzalkonium chloride (BAK) is the most commonly used and the most robustly studied. Several newer proprietary preservation systems-such as Polyquad, Purite, and SofZiahave been developed to mitigate undesirable attributes of BAK; these are particularly useful in glaucoma medications given the chronic polytherapy nature of glaucoma and the resulting extensive preservative exposure. Various others of these preservative classes have both intrinsic antibacterial and antifungal activity and are commonly used in contact lens solutions, artificial tears, and rewetting drops to reduce the risk of contact lensassociated fungal keratitis.

Of these many molecules, Benzalkonium chloride (BAK) is used in approximately $70 \%$ of ophthalmic formulations $[8,9]$ and is thus the focus of this paper. BAK is a quaternary ammonium compound with both hydrophilic and hydrophobic elements that renders it highly hydrosoluble $[3,8]$. Bactericidal activity occurs via interactions of BAK with bacterial cell membranes, leading to membrane instability and cell lysis [8]. BAK is effective against both Gram-positive and Gram- negative bacteria as well as fungi [3]. BAK may also act as a corneal penetration enhancer, leading to great ocular penetrance of active ingredients in BAK-preserved formulations $[3,10,11]$.

The monograph aims to review the adverse effects of acute and chronic exposure to BAK and to describe options for reducing or eliminating exposure to BAK and other preservatives in topical ophthalmic medical therapy.

\section{CYTOTOXIC EFFECTS OF BAK ON OCULAR TISSUES}

The cytotoxic effects of BAK on ocular tissue cells have been extensively documented (Table 2). The threshold concentration at which toxicity occurs has been estimated to be $\sim 0.005 \%$; as a preservative in topical ophthalmic formulations, BAK is commonly used in concentrations of $0.04-0.02 \%$ [3]. In both tissue culture and in animal models, BAK has been shown to reduce the survival of corneal [12-18], conjunctival [12, 13], trabecular meshwork (TM) $[19,20]$, and ciliary epithelial [19] cells. In animal models, BAK caused injury to corneal epithelial cells [15, 21, 22], loss of conjunctival goblet cells $[22,23]$, and delayed corneal wound healing [24]. BAK also induces lymphocyte infiltration of conjunctival epithelium and stroma in animal models [21, 22] and increases the levels of inflammatory markers in ocular tissues $[15,16,18]$. DNA fragmentation and oxidative damage have been demonstrated in TM cells exposed to BAK, leading to altered gene expression in these cells [20]. Further, BAK exposure induces corneal epithelial cell apoptosis [18]. Clinical studies suggest that these effects may be at least partially reversible upon withdrawal of BAK exposure [25-30].

The underlying mechanism(s) by which BAK damages cells of the ocular tissues has not been fully elucidated. BAK is a quaternary

${ }^{1}$ Ocular Therapeutix, Inc, Bedford, Massachusetts, USA. ${ }^{凶}$ email: svantipalli@ocutx.com 
Table 1. Classes and representative molecules of common preservatives in ocular therapeutic formulations [2-7].

\begin{tabular}{|llll}
\hline Chemical class & Component(s) & Proprietary name (if applicable) & \multicolumn{1}{c}{$\begin{array}{c}\text { Commercial formulation } \\
\text { examples }\end{array}$} \\
\hline $\begin{array}{l}\text { Quaternary ammoniums } \\
\text { (detergents) }\end{array}$ & Benzalkonium chloride & Many \\
\hline & Polyquaternium-1 & Polyquad (Alcon) & Travoprost PQ \\
\hline Polyquaternium-42 & & Some artificial tears \\
\hline Cetridizing agents & Sodium perborate & $\begin{array}{l}\text { GenAqua (Novartis), Dequest } \\
\text { (TheraTears) }\end{array}$ & Some artificial tears \\
\hline lonic buffers & $\begin{array}{l}\text { Stabilized Oxochloro } \\
\text { Complex (SOC) }\end{array}$ & $\begin{array}{l}\text { Purite (Allergan, an AbbVie company), } \\
\text { OcuPure (AMO) }\end{array}$ & Brimonidine P \\
\hline Amidines & $\begin{array}{l}\text { Borate, sorbitol, propylene glycol, } \\
\text { and zinc }\end{array}$ & SofZia (Alcon) & Travoprost Z \\
\hline Parabens & Chlorhexidine & & Some contact lens solutions \\
\hline Alcohols & Methylparaben & & Some artificial tears \\
\hline Mercury-based & Propylparaben & & Some artificial tears \\
\hline
\end{tabular}

Table 2. Cytotoxic effects of BAK on ocular tissues.

Decreased corneal, [12-18] conjunctival, $[12,13]$ trabecular meshwork, $[19,20]$ and ciliary epithelial cell $[19]$ survival

Corneal epithelial cell injury $[15,21,22]$

Conjunctival goblet cell loss $[22,23]$

Delayed corneal wound healing [24]

Lymphocyte infiltration of conjunctival epithelium and stroma [21, 22]

Elevates inflammatory marker concentrations in ocular tissues [15, 16, 18]

DNA fragmentation and oxidative damage in TM cells leading to altered gene expression [20]

ammonium compound and is thus cationic, so it is possible that BAK interacts with mitochondria, which are the only negatively charged intracellular compartment. Short-term exposure to cultured conjunctival epithelial cells stimulates the production of hydrogen peroxide, a reactive oxygen molecule, resulting in partial mitochondrial dysfunction [31]. BAK has also been shown to trigger oxidative stress in mitochondria and mitochondrial fragmentation [32], and to inhibit mitochondrial function by $>90 \%$ [33]. Mitochondrial oxidative stress is known to play a role in the development of ocular surface disease [34] as well as age-related corneal diseases and normal corneal aging [35].

\section{CLINICAL IMPACT OF BAK IN TOPICAL OPHTHALMIC THERAPEUTICS}

Most of what it is known about chronic BAK exposure comes from patients with glaucoma receiving chronic therapy with one or more BAK-preserved medications dosed one or more times daily. Given the known cytotoxic effects of BAK on the ocular surface, one would expect a higher rate of ocular surface disease (OSD) in eyes with chronic BAK exposure. In fact, the prevalence of OSD among glaucoma patients has been reported to be $30-70 \%$ in various studies [36-42], which is much higher than in the $5-30 \%$ prevalence among similarly-aged adults without glaucoma [43]. This higher than expected rate of OSD in glaucoma patients has been linked to BAK in topical glaucoma medications [1-4, 6, 44]. The total BAK "dose" (number of medications, number of drops per day, duration of therapy, etc.) correlates with OSD prevalence and severity in glaucoma patients [36-42]. Clinical manifestations of BAK-induced ocular surface toxicity in glaucoma patients using BAK-preserved medications (Table 3 ) include pain and discomfort (including stinging, burning, foreign body sensation, itching, and ocular dryness) [45, 46], tearing [46], increased staining of conjunctival and corneal epithelial surfaces [27, 46-48], increased tear break-up time $[25,27,30,46,47,49-51]$, lower Schirmer scores $[46,47]$, higher prevalence of punctate keratitis $[25,26,30]$, and overall worse scores on the Ocular Surface Disease Index (OSDI), a validated instrument for assessing the presence and severity of ocular surface symptoms [27, 30, 48, 49, 52, 53]. Other manifestations of chronic BAK exposure in eyes with glaucoma include conjunctival subepithelial inflammation and fibrosis $[9,54-56]$, which can reduce the success of subsequent filtering surgery $[9,57-59]$, as well as a higher rate of cataract surgery in eyes on long-term glaucoma therapy compared to those without such exposure $[60,61]$, potentially related to the known actions of BAK in increasing expression of inflammatory and apoptotic mediators in lens epithelial cells [62]. OSD as a comorbidity to glaucoma adversely affects the quality of life $[63,64]$, and the use of BAK-preserved medications has also been associated with worse quality of life than BAK-free medications $[47,52]$. Further, interactions between the two conditions can make both harder to manage [65].

Additional insight in BAK toxicity can be drawn from patients with OSD and allergy. OSD therapies are also formulated with preservatives, including BAK [66], which are known to cause or exacerbate OSD [67]. Topical anti-allergy medications preserved with BAK have also been shown to cause or aggravate OSD $[44,67]$, producing similar effects on the tissues of the ocular 
Table 3. Clinical manifestations of BAK toxicity.

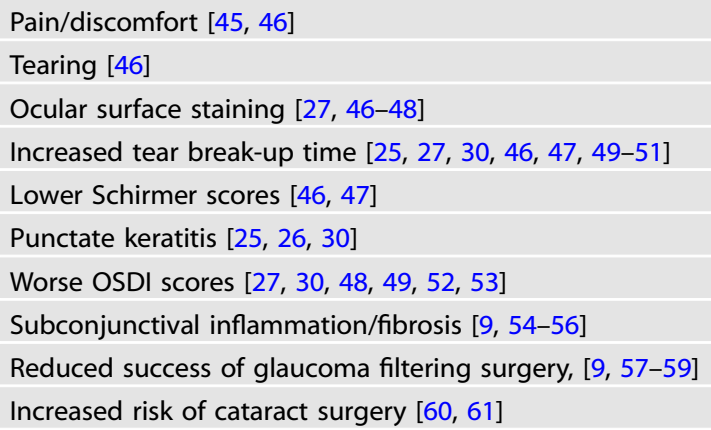

surface as were described for glaucoma and OSD above. Among patients with glaucoma and allergic conjunctivitis, a short 14-day course of BAK-preserved latanoprost increased eosinophil counts, altered results of the tear ferning test, and induced abnormalities in impression cytology [68], and even very brief exposure (one week) to BAK can induce goblet cell loss and induce other signs of OSD in subjects without preexisting OSD [69].

Also, BAK-preserved artificial tears alter the bacterial flora of the nasal mucosa reducing the population of Staphylococcus epidermidis [70], which could facilitate colonization with $S$. aureus species including pathogenic methicillin-resistant S. aureus [71, 72] as well as the influenza virus [73]. The effects of BAK on the novel human coronavirus SARS-CoV-2 - the agent responsible for the COVID-19 pandemic-are unknown, although as a disinfectant, BAK is less effective than other biocidal agents in eradicating the virus from inanimate surfaces [74].

The diagnosis of BAK toxicity is clinical in nature. The clinical manifestations of BAK toxicity occur in a spectrum from subclinical to severe and are often overlooked. The onset can be insidious and appear weeks or months after starting therapy, or only after a threshold number of medications or drops per day is reached, confounding the causal relationship to therapy. Mild signs may be overlooked by busy clinicians who either do not recognize the findings or choose not to address them in non-complaining patients. Likewise, patients may not report symptoms, particularly if therapy is achieving therapeutic efficacy goals, choosing instead to accept redness, discomfort, or even blurred vision as a price to pay for satisfactory glaucoma control. For patients who do report bothersome symptoms, the well-described disconnect between the signs and symptoms of ocular surface disease (OSD) can result in a lack of objective findings $[75,76]$, failure to make the diagnosis of BAK-mediated OSD, and a missed opportunity to adjust therapy and preserve or improve quality of life.

\section{APPROACHES TO MINIMIZE OR ELIMINATE BAK TOXICITY}

Given the frequency and severity of BAK-related ocular toxicity, it is worthwhile to review the therapeutic options that can ameliorate BAK toxicity or reduce or eliminate BAK exposure in patients requiring short-term or long-term topical ophthalmic medical therapy (Table 4).

The adverse effects of BAK can be ameliorated by adding preservative-free lubrication formulated with taurine to the BAKpreserved medical regimen, which has been shown to improve tear break-up time (TBUT), conjunctival goblet cell density, and Ocular Surface Disease Index (OSDI) and Glaucoma Symptom Scale (GSS) scores [77]. For patients using multiple BAK-formulated products-a common scenario in glaucoma management-switching to a fixed combination product can reduce BAK exposure by reducing the total number of drops administered per day [64].
Table 4. Strategies for reducing or eliminating BAK exposure.

Fixed combinations to reduce daily drop frequency

Co-administration of ameliorators of BAK toxicity

Use of medications preserved with alternatives to BAK

Use of non-preserved medications

Use of sustained drug delivery formulations

BAK exposure can be eliminated by using therapies formulated with preservatives other than BAK, by using preservative-free formulations (including emerging sustained drug delivery platforms), or by utilizing non-medical therapies (Table 4). Each of these options is discussed more fully below.

\section{Non-BAK preserved formulations}

A number of alternative preservatives have been developed for topical ophthalmic therapeutics that are collectively less harsh and better tolerated than BAK. The key drawback to these preservatives is that they are proprietary in nature and are thus limited to use-at least currently-in formulations produced by their manufacturer.

SofZia. SofZia (Alcon Laboratories, Fort Worth, TX) is an ionic buffered solution containing borate, sorbitol, propylene glycol and zinc [66] that creates an oxidizing antimicrobial milieu in multidose bottles that meets US Pharmacopeia (but not European Pharmacopoeia) standards [78]. The components degrade quickly upon contact with cations on the ocular surface [79] resulting in a preservation system that is less cytotoxic than BAK to ocular tissues [12-14, 19, 21, 23, 24]. In clinical studies, travoprost preserved with SofZia yielded better scores on surveys of ocular symptoms and quality of life compared to BAK-preserved travoprost [52]. Also, in eyes switched from BAK-preserved to SofZia-preserved travoprost, significant improvements were observed in both ocular signs and symptoms of OSD [25-27]. Importantly in the context of BAK's potential role in enhancing the penetration of active ingredients, there is no compromise of IOP control when BAK is replaced with SofZia in glaucoma medications [25-27].

Polyquad. Polyquad (Alcon) is a hydrophilic cationic quaternary ammonium polymer [80] 27 times larger than BAK [81] with a biocidal mechanism that involves damage to bacterial cytoplasmic membranes causing cell contents to leak out [82]. Its large size and lack of a hydrophobic region may prevent it from entering mammalian cells, thus reducing collateral toxicity to human cells [12]. Polyquad has been used in contact lens solutions [8] (where it does not form deposits on lenses) and in dry eye formulations [6] since the 1980s and more recently has been incorporated into formulations of glaucoma medications. Polyquad is significantly less cytotoxic to the ocular surface compared to $\operatorname{BAK}[12,15,19,22]$. In clinical studies, ocular symptom scores using the OSDI were lower (better) in eyes treated with Polyquad-preserved travoprost than with BAK-preserved travoprost, [53] and eyes switched from the BAK- to Polyquad-preserved formulation manifested improvements in both OSD sign and symptoms [28-30]. As with SofZia, replacing BAK with Polyquad did not affect the IOP-lowering efficacy of glaucoma medication formulations [28-30, 83].

Purite. Purite (Allergan, an Abbvie company, Chicago, IL) is a stabilized oxochloro complex (SOC) containing $99.5 \%$ chlorite, $0.5 \%$ chlorate, and trace chlorine dioxide that converts to sodium and chloride ions, oxygen, and water upon contact with the tear film [7]. Chlorine dioxide free radicals in solution impart Purite's antimicrobial activity; it is effective against bacteria and viruses [7]. Purite is less cytotoxic to the ocular surface than BAK [84-86]. In 
Table 5. Representative preservative-free topical formulations available for the treatment of glaucoma, ocular surface disease, and ocular allergy in the United States.

\begin{tabular}{ll}
\hline Drug class & Examples of commercial preservative-free formulations \\
Steroids & None \\
\hline NSAIDs & Acuvail (Allergan, an AbbVie company), Omidria (Omeros) \\
\hline Antibiotics & Vigamox (Novartis) \\
\hline Ocular hypotensives & Zioptan (Oak pharmaceutiicals), Cosopt PF (Merck), Timoptic in Ocudose (Bausch \& Lomb) \\
\hline Immunosuppressants & Restasis (Allergan, an AbbVie company), Cequa (Sun pharma) \\
\hline Antihistamines & Alaway (Bausch \& Lomb) \\
Hypertonics & Muro 128 (Bausch \& Lomb)
\end{tabular}

clinical studies, brimonidine preserved with Purite was better tolerated than BAK-preserved brimonidine in glaucoma patients with signs and/or symptoms of OSD and delivered comparable IOP reduction [87-89].

\section{Preservative-free formulations}

Select topical ophthalmic therapies for the treatment of glaucoma, OSD, and allergic eye disease, among others, are available in preservative-free formulations (examples given in Table 5). Collectively, as would be expected, these formulations demonstrate less cytotoxicity than their corresponding BAK-preserved formulations [14, 16-18]. In clinical studies, OSD signs and symptoms are consistently better with preservative-free versus preserved formulations [45-48, 50, 51, 90-100]. No compromise in IOP control has been identified with preservative-free versus preserved formulations of glaucoma medications [50,51,90,91, 93, 101]. The concentration of latanoprost free acid in the aqueous humour is above the threshold for prostaglandin receptor $\mathrm{F}$ activation following dosing with both BAK-preserved and preservative-free latanoprost [102].

Preservative-free formulations have significant limitations to be considered, the most important of which is that many topical therapies are not available in preservative-free formulations, and those that are available are almost without exception more expensive than their preserved counterparts and are subject to limited coverage by most insurers. These products are most commonly packaged as single-dose vials meant to be discarded after each use to prevent microbial contamination. This benefit is often thwarted by patients who save the vials after first use in order to extract subsequent doses before discarding. They are difficult for many patients-particularly older people at highest risk for age-related diseases such as glaucoma and OSD-to use. The vials are typically attached to one another and must be peeled apart. Instead of a screw-cap, they are opened by tearing the top of the plastic vial apart from the drug-containing reservoir, which requires some dexterity and can leave rough and/or sharp edges that can pose the risk of ocular surface injury if unintentional contact occurs between the vial and the eye during dosing. Their small size can make gripping and squeezing difficult, especially in patients with tremor or arthritis of the hands. Some of these obstacles can be overcome with multidose preservative-free formulations, but these are at risk of microbial contamination [103]. Systems to prevent microbial influx into multidose preservative-free formulations-such as the proprietary $A B A K$ and COMOD systems-have been developed and are available for a limited number of drugs [3]. Also, preservative-free liposomal eye sprays have been developed for the treatment of OSD [104].

\section{Preservative-free sustained drug delivery platforms}

Sustained drug delivery describes the administration of a single depot of preservative-free drug that is delivered to the target tissue(s) at the intended therapeutic concentration for a sustained period of time, avoiding the peaks and troughs of pulsed topical dosing. There are numerous advantages and disadvantages to these drug delivery platforms. As for advantages, these options reduce or eliminate the need for patient self-dosing, which in turn reduces or eliminates nonadherence and therefore may be associated with improved clinical outcomes and quality of life. Sustained drug delivery can significantly reduce the treatment burden imposed by daily topical dosing of glaucoma medications or reduce the frequency of intravitreal injections for ocular inflammatory disease, for example. Drugs can be delivered directly to target tissues, which may include the ocular surface to treat OSD, both the ocular surface and the anterior segment to treat glaucoma and postoperative inflammation, and the posterior segment to treat retinal diseases. Intraocular drug delivery spares the ocular surface exposure to active and excipient ingredients. Both steady-state and tapering drug levels can be delivered by sustained drug delivery platforms over time periods ranging from 30 days to three years by altering design elements.

Disadvantages of sustained drug delivery platforms include the need for administration by healthcare professionals in most cases, often via medical or surgical procedures that may incur procedure-related safety events in addition to drug-related side effects, although in some cases administration can be paired with planned surgical procedures to minimize added risk or exposure. Dose titration-strength/concentration, dosing schedule, etc.-is not possible as the daily dose delivered is a function of each platform's design. For intraocular platforms, it can be difficult or impossible to discontinue therapy before the drug is fully depleted, such that drug-related side effects may be difficult to manage. Existing platforms are designed for single-drug delivery only, which limits the value of these options for patients who require multiple drugs to manage their ocular condition(s). There is the theoretical possibility of reduced efficacy compared to standard pulse dosing, for example in the case of receptor saturation and downregulation with sustained release of prostaglandins for glaucoma therapy $[105,106]$. In addition, sustainedrelease formulations may be more expensive than their nonsustained release counterparts, and the value of these products' attributes may not be perceived as of sufficient value to payors to cover the added costs.

Sustained release technology is not new to ocular therapeutics. More than 40 years ago the Ocusert was a sustained delivery system that resided on the ocular surface in the conjunctival fornix and delivered pilocarpine for IOP control for a week at a time [107]. In the 1990s, a ganciclovir intravitreal implant was developed for the treatment of cytomegalovirus retinitis [108] before the development of highly active antiretroviral therapy all but eradicated CMV among patients with acquired immunodeficiency syndrome (AIDS). In more recent years, numerous novel sustained drug delivery platforms have been commercialized for a variety of ocular conditions and diseases, and many others are in various stages of preclinical and clinical development [109-112]. Several commercialized sustained drug delivery platforms are described below as examples of this rapidly evolving therapeutic frontier. 
Implants and Inserts. Durasert (EyePoint Pharmaceuticals, Watertown, MA) is a small, injectable sustained delivery system that can deliver small molecules at therapeutic concentrations for up to three years without the need for preservatives. This technology is based on a permeable polyvinyl alcohol membrane positioned between the drug reservoir and the device's aperture that controls the rate of drug elution. The platform is nonerodable and a capsule remains in the eye after complete drug elution. The system has been incorporated into several commercial products to treat a variety of chronic ocular conditions [113], including the aforementioned ganciclovir implant and three fluocinolone acetonide intravitreal implants (Retisert $0.59 \mathrm{mg}$, Bausch \& Lomb, Rochester, NY; lluvien 0.19 mg, Alimera Sciences, Alpharetta, GA; and Yutiq $0.18 \mathrm{mg}$, EyePoint). The Retisert device is classified as an implant as it is sutured to the inner eyewall via a surgical procedure, while the remaining 2 fluocinolone devices are inserts and can be injected without a surgical procedure.

The NOVADUR system (Allergan, an AbbVie company) is another notable sustained delivery system. In this system, the active drug is embedded in a polymer matrix of poly (D,L-lactideco-glycolide) (PLGA) that slowly degrades to lactic and glycolic acids which in turn degrade to water and carbon dioxide upon drug depletion, leaving no residue in the eye [113]. Two biodegradable injectable ocular inserts-a dexamethasone intravitreal insert for posterior segment inflammation (Ozurdex, dexamethasone $0.7 \mathrm{mg}$ ) and a bimatoprost anterior chamber insert for glaucoma therapy (Durysta, bimatoprost $10 \mathrm{mcg}$ ) have been commercialized by the manufacturer (Allergan, Dublin, Ireland) and provide preservative-free drug delivery for $\sim 6$ months.

Hydrogels are another promising sustained release drug delivery platform. Hydrogels are biocompatible hydrophilic crosslinked polymer networks that swell when exposed to water [114]. Active drug is incorporated into the polymer matrix without preservatives. The rate of drug delivery, and thus the duration of action of a hydrogel-based therapeutic, is determined by the degree of polymeric crosslinking and the relative sizes of the intercrosslink mesh openings and the drug to be delivered, the latter of which is fixed while the former of which can be varied in the design and synthesis processes $[114,115]$. The DEXTENZA intracanalicular insert (Ocular Therapeutix, Bedford, MA) is a preservative-free sustained-release formulation of dexamethasone $0.4 \mathrm{mg}$ encapsulated in a hydrogel sustained delivery system indicated for control of inflammation and pain following ophthalmic surgery. As it dissolves within the canaliculus, the insert delivers a tapering dose of dexamethasone to the tear film up to 30 days. Hydrogel-based sustained release therapeutics are also being developed for the treatment of ocular surface diseases and intracameral delivery of travoprost for glaucoma as well as intravitreal delivery of tyrosine kinase inhibitors for retinal vascular disorders [116, 117].

The Verisome platform (EyePoint) is a versatile sustained drug delivery platform that can deliver large or small molecules for periods ranging from weeks to months formulated into biodegradable solids, gels, or liquids [116]. Dexycu (EyePoint) is a 9\% suspension of dexamethasone delivered intraocularly at the time of surgery to control postoperative inflammation [116]. Upon injection, it coalesces to form a single spherule that biodegrades over $\sim 21$ days, releasing dexamethasone in a tapering dose over time.

\section{Non-Pharmacological Therapy}

At the extreme end of BAK avoidance is the eschewing of medication therapy altogether. While medication therapy is the preferred first-line approach for glaucoma treatment, laser therapy (selective laser trabeculoplasty) [118], minimally invasive glaucoma surgeries [119-122], and even primary filtering surgery [123, 124] can be considered alternatives to medication therapy. For the management of OSD, punctal plugs, intranasal neurostimulation, and Meibomian heat therapy are all non-medication options [125]. Further, for allergic eye disease, allergen immunotherapy is an alternative to topical medical therapy [126].

\section{UNMET NEED AND FUTURE DEVELOPMENTS}

BAK is nearly ubiquitous in topical ophthalmic formulations and is associated with multiple adverse effects on ocular health that are aggravated with chronic exposure. As discussed above, there are many options for alternate therapies to treat a variety of conditions in patients for whom BAK avoidance is desired or necessary. Many of these, however, have limitations, including expense, availability, invasiveness, and a reduction or elimination of dose titration. There remains a significant unmet need for further development of widely available, and easy-to-administer BAK-free therapies for common ocular conditions. Innovation in bottle design might reduce preservative exposure at the point of dosing $[66,127,128]$. Novel excipients could be added to BAKpreserved formulations to diminish adverse effects without altering biocidal activity [129]. Alternate preservatives that are less damaging to the ocular surface would have value [130], and expanding the range of commonly-used medications available in preservative-free formulations would make a broad impact as well, particularly if packaging can be redesigned to optimize userfriendliness. Of particular impact would be the expansion of sustained drug delivery platforms and products to provide preservative-free therapeutic options that eliminate the need for patient adherence. These would have the greatest impact in chronic conditions where reductions in treatment burden can contribute to improved quality of life. Most importantly, the prioritization of preservative-free therapy to spare the ocular surface will require recognition and valuation by health payors to ensure that patients have affordable access to existing and emerging therapeutic options.

\section{REFERENCES}

1. Rasmussen CA, Kaufman PL, Kiland JA. Benzalkonium chloride and glaucoma. J Ocul Pharm Ther. 2014;30:163-9.

2. Steven DW, Alaghband $\mathrm{P}$, Lim KS. Preservatives in glaucoma medication. $\mathrm{Br} \mathrm{J}$ Ophthalmol. 2018;102:1497-503.

3. Baudouin C, Labbé A, Liang $\mathrm{H}$, Pauly A, Brignole-Baudouin F. Preservatives in eyedrops: the good, the bad and the ugly. Prog Retin Eye Res. 2010;29:312-34.

4. Coroi MC, Bungau S, Tit M. Preservatives from the eye drops and the ocular surface. Rom J Ophthalmol. 2015;59:2-5.

5. Ittoop SM, Seibold LK, Kahook MY. Ocular Surface Disease and the Role of Preservatives in Glaucoma Medications. In: Shaarawy T, Sherwood MB, Hitchings RA, Crowston JG, editors. Glaucoma: Medical Diagnosis and Therapy. 1. 2nd ed. London: Elsevier; 2015. p. 593-7.

6. Kaur IP, Lal S, Rana C, Kakkar S, Singh H. Ocular preservatives: associated risks and newer options. Cutan Ocul Toxicol. 2009;28:93-103.

7. Noecker R. Effects of common ophthalmic preservatives on ocular health. Adv Ther. 2001;18:205-15.

8. Freeman PD, Kahook MY. Preservatives in topical ophthalmic medications: historical and clinical perspectives. Expert Rev Ophthalmol. 2009;4:59-64.

9. Broadway DC, Grierson I, O'Brien C, Hitchings RA. Adverse effects of topical antiglaucoma medication. ii. the outcome of filtration surgery. Arch Ophthalmol. 1994;112:1446-54.

10. Majumdar S, Hippalgaonkar K, Repka MA. Effect of chitosan, benzalkonium chloride and ethylenediaminetetraacetic acid on permeation of acyclovir across isolated rabbit cornea. Int J Pharm. 2008;348:175-8.

11. Yenice I, Mocan MC, Palaska E, Bochot A, Bilensoy E, Vural I, et al. Hyaluronic acid coated poly-epsilon-caprolactone nanospheres deliver high concentrations of cyclosporine a into the cornea. Exp Eye Res. 2008;87:162-7.

12. Ammar DA, Noecker RJ, Kahook MY. Effects of benzalkonium chloride-preserved, polyquad-preserved, and sofzia-preserved topical glaucoma medications on human ocular epithelial cells. Adv Ther. 2010;27:837-45.

13. Ayaki M, Iwasawa A. Cytotoxicity of prostaglandin analog eye drops preserved with benzalkonium chloride in multiple corneoconjunctival cell lines. Clini ophthalmol (Auckland, NZ). 2010;4:919-24. 
14. Ayaki M, Iwasawa A, Inoue Y. Toxicity of antiglaucoma drugs with and without benzalkonium chloride to cultured human corneal endothelial. cells. Clin ophthalmol (Auckland, NZ). 2010;4:1217-22.

15. Kim JH, Kim EJ, Kim YH, Kim Yl, Lee SH, Jung JC, et al. In vivo effects of preservative-free and preserved prostaglandin analogs: mouse ocular surface study. Korean J Ophthalmol. 2015;29:270-9.

16. Kim YH, Jung JC, Jung SY, Yu S, Lee KW, Park YJ. Comparison of the efficacy of fluorometholone with and without benzalkonium chloride in ocular surface disease. Cornea 2016;35:234-42.

17. Guzman-Aranguez A, Calvo P, Ropero I, Pintor J. In vitro effects of preserved and unpreserved anti-allergic drugs on human corneal epithelial cells. J Ocul Pharm Ther. 2014;30:790-8.

18. Pauly A, Brasnu E, Riancho L, Brignole-Baudouin F, Baudouin C. Multiple endpoint analysis of bac-preserved and unpreserved antiallergic eye drops on a 3dreconstituted corneal epithelial model. Mol Vis. 2011;17:745-55.

19. Ammar DA, Kahook MY. Effects of glaucoma medications and preservatives on cultured human trabecular meshwork and non-pigmented ciliary epithelial cell lines. Br J Ophthalmol. 2011;95:1466-9.

20. Izzotti A, La Maestra S, Micale RT, Longobardi MG, Sacca SC. Genomic and postgenomic effects of anti-glaucoma drugs preservatives in trabecular meshwork. Mutat Res. 2015;772:1-9.

21. Kahook MY, Noecker RJ. Comparison of corneal and conjunctival changes after dosing of travoprost preserved with sofzia, latanoprost with $0.02 \%$ benzalkonium chloride, and preservative-free artificial tears. Cornea 2008;27:339-43.

22. Liang $H$, Brignole-Baudouin $F$, Riancho $L$, Baudouin $C$. Reduced in vivo ocular surface toxicity with polyquad-preserved travoprost versus benzalkoniumpreserved travoprost or latanoprost ophthalmic solutions. Ophthalmic Res. 2012;48:89-101.

23. Kahook MY, Noecker R. Quantitative analysis of conjunctival goblet cells after chronic application of topical drops. Adv Ther. 2008;25:743-51.

24. Nagai N, Murao T, Okamoto N, Ito Y. Comparison of corneal wound healing rates after instillation of commercially available latanoprost and travoprost in rat debrided corneal epithelium. J Oleo Sci. 2010;59:135-41.

25. Aihara M, Oshima $H$, Araie M. Effects of sofzia-preserved travoprost and benzalkonium chloride-preserved latanoprost on the ocular surface-a multicentre randomized single-masked study. Acta Ophthalmol. 2013;91:e7-e14.

26. Aihara $M$, Ikeda $Y$, Mizoue $S$, Arakaki $Y$, Kita $N$, Kobayashi $S$, et al. Effect of switching to travoprost preserved with sofzia in glaucoma patients with chronic superficial punctate keratitis while receiving bak-preserved latanoprost. J Glaucoma. 2016;25:e610-4.

27. Horsley MB, Kahook MY. Effects of prostaglandin analog therapy on the ocular surface of glaucoma patients. Clin ophthalmol (Auckland, NZ). 2009;3:291-5.

28. Garcia-Feijoo J, Munoz-Negrete FJ, Hubatsch DA, Rossi GC. Efficacy and tolerability of benzalkonium chloride-free travoprost in glaucoma patients switched from benzalkonium chloride-preserved latanoprost or bimatoprost. Clin ophthalmol (Auckland, NZ). 2016;10:2085-91.

29. Lopes JF, Hubatsch DA, Amaris P. Effect of benzalkonium chloride-free travoprost on intraocular pressure and ocular surface symptoms in patients with glaucoma previously on latanoprost: an open-label study. BMC Ophthalmol. 2015;15:166.

30. Rossi GC, Scudeller L, Rolle T, Pasinetti GM, Bianchi PE. From benzalkonium chloride-preserved latanoprost to polyquad-preserved travoprost: a 6-month study on ocular surface safety and tolerability. Expert Opin drug Saf. 2015;14:619-23.

31. Debbasch C, Brignole F, Pisella PJ, Warnet JM, Rat P, Baudouin C. Quaternary ammoniums and other preservatives' contribution in oxidative stress and apoptosis on chang conjunctival cells. Investigative Ophthalmol Vis Sci. 2001;42:642-52.

32. Rogov AG, Goleva TN, Sukhanova El, Epremyan KK, Trendeleva TA, Ovchenkova $A P$, et al. Mitochondrial dysfunctions may be one of the major causative factors underlying detrimental effects of benzalkonium chloride. Oxid Med Cell Longev. 2020;2020:8956504

33. Datta S, Baudouin C, Brignole-Baudouin F, Denoyer A, Cortopassi GA. The eye drop preservative benzalkonium chloride potently induces mitochondrial dysfunction and preferentially affects Ihon mutant cells. Investigative Ophthalmol Vis Sci. 2017;58:2406-12.

34. Uchino $Y$, Kawakita T, Miyazawa M, Ishii T, Onouchi H, Yasuda K, et al. Oxidative stress induced inflammation initiates functional decline of tear production. PLoS ONE. 2012;7:e45805.

35. Onouchi H, Ishii T, Miyazawa M, Uchino Y, Yasuda K, Hartman PS, et al. Mitochondrial superoxide anion overproduction in Tet-Mev-1 transgenic mice accelerates age-dependent corneal cell dysfunctions. Investigative Ophthalmol Vis Sci. 2012;53:5780-7.

36. Labbe A, Terry O, Brasnu E, Van Went C, Baudouin C. Tear film osmolarity in patients treated for glaucoma or ocular hypertension. Cornea 2012;31:994-9.
37. O'Hare F, Ghosh S, Lamoureux E, Vajpayee RB, Crowston JG. Prevalence of signs and symptoms of ocular surface disease in individuals treated and not treated with glaucoma medication. Clin Exp Ophthalmol. 2012;40:675-81.

38. Valente $C$, lester M, Corsi E, Rolando M. Symptoms and signs of tear film dysfunction in glaucomatous patients. J Ocul Pharm Ther. 2011;27:281-5.

39. Leung EW, Medeiros FA, Weinreb RN. Prevalence of ocular surface disease in glaucoma patients. J Glaucoma. 2008;17:350-5.

40. Fechtner RD, Godfrey DG, Budenz D, Stewart JA, Stewart WC, Jasek MC. Prevalence of ocular surface complaints in patients with glaucoma using topical intraocular pressure-lowering medications. Cornea 2010;29:618-21.

41. Rossi GC, Pasinetti GM, Scudeller L, Raimondi M, Lanteri S, Bianchi PE. Risk factors to develop ocular surface disease in treated glaucoma or ocular hypertension patients. Eur J Ophthalmol. 2013;23:296-302.

42. Skalicky SE, Goldberg I, McCluskey P. Ocular surface disease and quality of life in patients with glaucoma. Am J Ophthalmol. 2011;153:1-9 e2.

43. Stapleton F, Alves M, Bunya VY, Jalbert I, Lekhanont $K$, Malet F, et al. Tfos dews li epidemiology report. Ocul Surf. 2017;15:334-65.

44. Fraunfelder FT, Sciubba JJ, Mathers WD. The role of medications in causing dry eye. J Ophthalmol. 2012;2012:285851.

45. Jaenen N, Baudouin C, Pouliquen P, Manni G, Figueiredo A, Zeyen T. Ocular symptoms and signs with preserved and preservative-free glaucoma medications. Eur J Ophthalmol. 2007;17:341-9.

46. Uusitalo H, Egorov E, Kaarniranta K, Astakhov Y, Ropo A. Benefits of switching from latanoprost to preservative-free tafluprost eye drops: a metaanalysis of two phase iiib. clinical trials. Clin ophthalmol (Auckland, NZ.2016;10:445-54

47. Hommer A, Kimmich F. Switching patients from preserved prostaglandin-analog monotherapy to preservative-free tafluprost. Clin ophthalmol (Auckland, NZ). 2011;5:623-31.

48. Lopes NLV, Gracitelli CPB, Chalita MR, de Faria NVL. Ocular surface evaluation after the substitution of benzalkonium chloride preserved prostaglandin eye drops by a preservative-free prostaglandin analogue. Med Hypothesis Disco Innov Ophthalmol. 2019;8:52-6.

49. Tomic M, Kastelan S, Soldo KM, Salopek-Rabatic J. Influence of bak-preserved prostaglandin analog treatment on the ocular surface health in patients with newly diagnosed primary open-angle glaucoma. Biomed Res Int. 2013;2013:603782.

50. Economou MA, Laukeland HK, Grabska-Liberek I, Rouland JF. Better Tolerance of Preservative-Free Latanoprost Compared to Preserved Glaucoma Eye Drops: The 12-Month Real-Life Free Study. Clinical ophthalmology (Auckland, NZ). 2018;12:2399-407.

51. Lazreg S, Merad Z, Nouri MT, Garout R, Derdour A, Ghroud N, et al. Efficacy and safety of preservative-free timolol $0.1 \%$ gel in open-angle glaucoma and ocular hypertension in treatment-naive patients and patients intolerant to other hypotensive medications. J francais d'ophtalmologie. 2018;41:945-54.

52. Kumar S, Singh T, Ichhpujani P, Vohra S, Thakur S. Correlation of ocular surface disease and quality of life in indian glaucoma patients: bac-preserved versus bac-free travoprost. Turk J Ophthalmol. 2020;50:75-81.

53. Kumar S, Singh T, Ichhpujani P, Vohra S. Ocular surface disease with bak preserved travoprost and polyquaternium 1(polyquad) preserved travoprost. Rom J Ophthalmol. 2019;63:249-56

54. Huang C, Wang H, Pan J, Zhou D, Chen W, Li W, et al. Benzalkonium chloride induces subconjunctival fibrosis through the Cox-2-modulated activation of a Tgf-Beta1/Smad3 signaling pathway. Investigative Ophthalmol Vis Sci. 2014;55:8111-22.

55. Baudouin C, Pisella PJ, Fillacier K, Goldschild M, Becquet F, De Saint Jean M, et al. Ocular surface inflammatory changes induced by topical antiglaucoma drugs: human and animal studies. Ophthalmology 1999;106:556-63.

56. Sherwood MB, Grierson I, Millar L, Hitchings RA. Long-term morphologic effects of antiglaucoma drugs on the conjunctiva and tenon's capsule in glaucomatous patients. Ophthalmology 1989;96:327-35.

57. Chamard C, Larrieu S, Baudouin C, Bron A, Villain M, Daien V. Preservative-free versus preserved glaucoma eye drops and occurrence of glaucoma surgery. a retrospective study based on the french national health insurance information system, 2008-2016. Acta Ophthalmol. 2020;98:e876-e81.

58. Boimer C, Birt CM. Preservative exposure and surgical outcomes in glaucoma patients: the Peso study. J Glaucoma. 2013;22:730-5.

59. Lavin MJ, Wormald RP, Migdal CS, Hitchings RA. The influence of prior therapy on the success of trabeculectomy. Arch Ophthalmol. 1990;108:1543-8.

60. Herman DC, Gordon MO, Beiser JA, Chylack LT Jr., Lamping KA, Schein OD, et al. Topical ocular hypotensive medication and lens opacification: evidence from the ocular hypertension treatment study. Am J Ophthalmol. 2006; 142:800-10.

61. Chandrasekaran S, Cumming RG, Rochtchina E, Mitchell P. Associations between elevated intraocular pressure and glaucoma, use of glaucoma medications, and 
5-year incident cataract: The Blue Mountains Eye Study. Ophthalmology 2006;113:417-24.

62. Goto Y, Ibaraki N, Miyake K. Human lens epithelial cell damage and stimulation of their secretion of chemical mediators by benzalkonium chloride rather than latanoprost and timolol. Arch Ophthalmol. 2003;121:835-9.

63. Rossi GC, Tinelli C, Pasinetti GM, Milano G, Bianchi PE. Dry eye syndrome-related quality of life in glaucoma patients. Eur J Ophthalmol. 2009;19:572-9.

64. Rossi GC, Pasinetti GM, Scudeller L, Bianchi PE. Ocular surface disease and glaucoma: how to evaluate impact on quality of life. J Ocul Pharm Ther. 2013;29:390-4.

65. Batra R, Tailor R, Mohamed S. Ocular surface disease exacerbated glaucoma: optimizing the ocular surface improves intraocular pressure control. J Glaucoma. 2014;23:56-60.

66. Walsh K, Jones L. The use of preservatives in dry eye drops. Clin ophthalmol (Auckland, NZ). 2019;13:1409-25.

67. Gomes JAP, Azar DT, Baudouin C, Efron N, Hirayama M, Horwath-Winter J, et al. Tfos Dews li latrogenic report. Ocul Surf. 2017;15:511-38.

68. Costagliola C, Prete AD, Incorvaia C, Fusco R, Parmeggiani F, Di, et al. Ocular surface changes induced by topical application of latanoprost and timolol: a short-term study in glaucomatous patients with and without allergic conjunctivitis. Graefes Arch Clin Exp Ophthalmol. 2001;239:809-14.

69. Rolando M, Brezzo V, Giodano G, Campagna P, Burlando S, Calabria G. The effect of different benzalkonium chloride concentrations on human normal ocular surface. In: Van Bijsterveld O, Lemp M, Spinelli D, editors. The Lacrimal System. Amsterdam, Berkeley, Milano: Kugler and Ghedini Publications; 1991. pp. 87-91.

70. Onerci Celebi O, Celebi ARC. The effect of ocular lubricants containing benzalkonium chloride on nasal mucosal flora. Cutan Ocul Toxicol. 2018;37:305-8.

71. Lina G, Boutite F, Tristan A, Bes M, Etienne J, Vandenesch F. Bacterial competition for human nasal cavity colonization: role of Staphylococcal Agr alleles. Appl Environ Microbiol. 2003;69:18-23.

72. Iwase T, Uehara Y, Shinji H, Tajima A, Seo H, Takada K, et al. Staphylococcus epidermidis ESP inhibits staphylococcus aureus biofilm formation and nasal colonization. Nature 2010;465:346-9.

73. Chen HW, Liu PF, Liu YT, Kuo S, Zhang XQ, Schooley RT, et al. Nasal commensal staphylococcus epidermidis counteracts influenza virus. Sci Rep. 2016;6:27870.

74. Kampf G, Todt D, Pfaender S, Steinmann E. Persistence of coronaviruses on inanimate surfaces and their inactivation with biocidal agents. J Hosp Infect. 2020;104:246-51.

75. Sullivan BD, Crews LA, Messmer EM, Foulks GN, Nichols KK, Baenninger P, et al. Correlations between commonly used objective signs and symptoms for the diagnosis of dry eye disease: clinical implications. Acta ophthalmologica. 2014;92:161-6.

76. Nichols KK, Nichols JJ, Mitchell GL. The lack of association between signs and symptoms in patients with dry eye disease. Cornea 2004;23:762-70.

77. Roberti G, Agnifili L, Berardo F, Riva I, Figus M, Manni G, et al. Prospective, randomized, single masked, parallel study exploring the effects of a preservative-free ophthalmic solution containing hyaluronic acid $0.4 \%$ and taurine $0.5 \%$ on the ocular surface of glaucoma patients under multiple longterm topical hypotensive therapy. Adv Ther. 2018;35:686-96.

78. Ryan G Jr., Fain JM, Lovelace C, Gelotte KM. Effectiveness of ophthalmic solution preservatives: a comparison of latanoprost with $0.02 \%$ benzalkonium chloride and travoprost with the sofzia preservative system. BMC Ophthalmol. 2011;11:8.

79. Actis $A G$, Rolle T. Ocular surface alterations and topical antiglaucomatous therapy: a review. open Ophthalmol J. 2014;8:67-72.

80. Good RM Jr., Liao JC, Hook MJ, Punko CL. Colorimetric determination of a polymeric quaternary ammonium antimicrobial preservative in an ophthalmic solution. J Assoc Anal Chem. 1987;70:979-80.

81. Rolando M, Crider JY, Kahook MY. Ophthalmic preservatives: focus on polyquaternium-1. Expert Opin drug Deliv. 2011;8:1425-38.

82. Codling CE, Hann AC, Maillard JY, Russell AD. An investigation into the antimicrobial mechanisms of action of two contact lens biocides using electron microscopy. Cont Lens Anterior Eye. 2005;28:163-8.

83. Peace JH, Ahlberg P, Wagner M, Lim JM, Wirta D, Branch JD. Polyquaternium-1preserved travoprost $0.003 \%$ or benzalkonium chloride-preserved travoprost $0.004 \%$ for glaucoma and ocular hypertension. Am J Ophthalmol. 2015;160:266-74 e1.

84. Noecker RJ, Herrygers LA, Anwaruddin R. Corneal and conjunctival changes caused by commonly used glaucoma medications. Cornea 2004;23:490-6.

85. Dutescu RM, Panfil C, Schrage N. Comparison of the effects of various lubricant eye drops on the in vitro rabbit corneal healing and toxicity. Exp Toxicol Pathol. 2017;69:123-9.

86. Schrage N, Frentz M, Spoeler F. The ex vivo eye irritation test (Eveit) in evaluation of artificial tears: purite-preserved versus unpreserved eye drops. Graefes Arch Clin Exp Ophthalmol. 2012;250:1333-40.
87. Mundorf T, Wilcox KA, Ousler GW 3rd, Welch D, Abelson MB. Evaluation of the comfort Of Alphagan P compared with Alphagan in irritated eyes. Adv Ther. 2003;20:329-36.

88. Mundorf T, Williams R, Whitcup S, Felix C, Batoosingh A. A 3-month comparison of efficacy and safety of Brimonidine-purite $0.15 \%$ and Brimonidine $0.2 \%$ in patients with glaucoma or ocular hypertension. J Ocul Pharm Ther. 2003;19:37-44.

89. Katz LJ. Twelve-month evaluation of brimonidine-purite versus brimonidine in patients with glaucoma or ocular hypertension. J Glaucoma. 2002;11:119-26.

90. Aptel F, Pfeiffer N, Schmickler S, Clarke J, Lavin-Dapena C, Moreno-Montanes J, et al. Noninferiority of preservative-free versus bak-preserved latanoprosttimolol fixed combination eye drops in patients with open-angle glaucoma or ocular hypertension. J Glaucoma. 2019;28:498-506.

91. Lee W, Lee $\mathrm{S}, \mathrm{Bae} \mathrm{H}, \mathrm{Kim} \mathrm{CY}$, Seong GJ. Efficacy and tolerability of preservativefree $0.0015 \%$ tafluprost in glaucoma patients: a prospective crossover study. BMC Ophthalmol. 2017;17:61.

92. Mohammed I, Kulkarni B, Faraj LA, Abbas A, Dua HS, King AJ. Profiling ocular surface responses to preserved and non-preserved topical glaucoma medications: a 2-year randomized evaluation study. Clin Exp Ophthalmol. 2020;48:973-82.

93. Goldberg I, Graham SL, Crowston JG, d'Mellow G, Australian, New Zealand Glaucoma Interest $\mathrm{G}$. Clinical audit examining the impact of benzalkonium chloride-free anti-glaucoma medications on patients with symptoms of ocular surface disease. Clin Exp Ophthalmol. 2015;43:214-20.

94. Kestelyn PA, Kestelyn PG, De Bacquer D, Stevens AM. Switch from bak-preserved to preservative-free latanoprost decreases anterior chamber flare in poag patients. Int Ophthalmol. 2019;39:105-9.

95. Jun I, Choi S, Lee GY, Choi YJ, Lee HK, Kim EK, et al. Effects of preservative-free $3 \%$ diquafosol in patients with pre-existing dry eye disease after cataract surgery: a randomized clinical trial. Sci Rep. 2019;9:12659.

96. Nasser L, Rozycka M, Gomez Rendon G, Navas A. Real-life results of switching from preserved to preservative-free artificial tears containing hyaluronate in patients with dry eye disease. Clin ophthalmol (Auckland, NZ). 2018;12:1519-25.

97. Allaire C, Siou-Mermet R, Bassols A. [Safety and efficacy of a new preservativefree levocabastine ophthalmic solution (Levofree(R)) using the conjunctival provocation test]. Journal francais d'ophtalmologie. 2012;35:491-8.

98. Beden C, Helleboid L, Marmouz F, Liard F. [a comparative study of the ocular tolerance after administration of anti-allergic eye drops with or without a preservative]. Therapie. 2004;59:259-64.

99. Leonardi A, Capobianco D, Benedetti N, Capobianco A, Cavarzeran F, Scalora T, et al. Efficacy and tolerability of ketotifen in the treatment of seasonal allergic conjunctivitis: comparison between ketotifen $0.025 \%$ and $0.05 \%$ eye drops. Ocul Immunol Inflamm. 2019;27:1352-6.

100. Boboridis KG, Kozeis N, Konstas AG. Revisiting ocular allergy: evaluating symptoms, benzalkonium chloride and efficacy of topical ketotifen 0.025 . Ocul Immunol Inflamm. 2020;28:188-90.

101. Duru Z, Ozsaygili C. Preservative-free versus preserved brimonidine $\% 0.15$ preparations in the treatment of glaucoma and ocular hypertension: short term evaluation of efficacy, safety, and potential advantages. Cutan Ocul Toxicol. 2020;39:21-4.

102. Sekine $Y$, Shimada M, Satake S, Okubo M, Hisaka A, Hara T, et al. Pharmacokinetic analysis of intraocular penetration of latanoprost solutions with different preservatives in human eyes. J Ocul Pharm Ther. 2018;34:280-6.

103. Saisyo A, Shimono R, Oie S, Kimura K, Furukawa H. The risk of microbial contamination in multiple-dose preservative-free ophthalmic preparations. Biol Pharm Bull. 2017;40:182-6.

104. Pult $\mathrm{H}$, Gill $\mathrm{F}$, Riede-Pult BH. Effect of three different liposomal eye sprays on ocular comfort and tear film. Cont Lens Anterior Eye. 2012;35:203-7. ; quiz 43-4

105. Brandt JD, Sall K, DuBiner H, Benza R, Alster Y, Walker G, et al. Six-month intraocular pressure reduction with a topical bimatoprost ocular insert: results of a phase ii randomized controlled study. Ophthalmology 2016;123:1685-94.

106. Linden C, Alm A. Latanoprost twice daily is less effective than once daily: indication of receptor subsensitivity? Curr Eye Res. 1998;17:567-72.

107. Bensinger R, Shin DH, Kass MA, Podos SM, Becker B. Pilocarpine ocular inserts. Investigative Ophthalmol. 1976;15:1008-10.

108. Chiron vision files fda application to market intraocular implant for $\mathrm{cmv}$ retinitis. food and drug administration. J Int Assoc Physicians AIDS Care. 1995;1:37.

109. Singh RB, Ichhpujani $P$, Thakur S, Jindal S. Promising therapeutic drug delivery systems for glaucoma: a comprehensive review. Ther Adv Ophthalmol 2020;12:2515841420905740.

110. Kang-Mieler JJ, Rudeen KM, Liu W, Mieler WF. Advances in ocular drug delivery systems. Eye (Lond). 2020;34:1371-9.

111. Rafiei F, Tabesh H, Farzad F. Sustained subconjunctival drug delivery systems: current trends and future perspectives. Int Ophthalmol. 2020;40:2385-401. 
112. Souto EB, Dias-Ferreira J, Lopez-Machado A, Ettcheto M, Cano A, Camins Espuny A, et al. Advanced Formulation Approaches for Ocular Drug Delivery: State-OfThe-Art and Recent Patents. Pharmaceutics. 2019;11:460.

113. Haghjou N, Soheilian M, Abdekhodaie MJ. Sustained release intraocular drug delivery devices for treatment of uveitis. J Ophthalmic Vis Res. 2011; 6:317-29.

114. Peppas NA, Hilt JZ, Khademhosseini A, Langer R. Hydrogels in biology and medicine: from molecular principles to bionanotechnology. Adv Mater. 2006; 18:1345-60

115. Amin S, Rajabnezhad S, Kohli K. Hydrogels as potential drug delivery systems. Sci Res Essays. 2009:3:1175-83.

116. Kang-Mieler JJ, Rudeen KM, Liu W, Mieler WF. New ocular drug delivery systems. In: Chang A, Mieler WF, Ohji M, editors. Macular Surgery. Singapore: Springer; 2020. p. 577-91.

117. Vanslette A, Haberman $P$, Blizzard CD, Driscoll A, Vantipalli S, Metzinger JL, et al. Evaluating Safety and Pharmacokinetics of OTX-CSI, a Sustained Release Intracanalicular Cyclosporine Insert in Beagles. Invest Ophthalmol Vis Sci. 2020;61:325858.

118. Gazzard G, Konstantakopoulou E, Garway-Heath D, Garg A, Vickerstaff V, Hunter $\mathrm{R}$, et al. Selective laser trabeculoplasty versus eye drops for first-line treatment of ocular hypertension and glaucoma (light): a multicentre randomised controlled trial. Lancet 2019;393:1505-16.

119. Richter GM, Coleman AL. Minimally invasive glaucoma surgery: current status and future prospects. Clin Ophthalmol. 2016;10:189-206.

120. Lavia C, Dallorto L, Maule M, Ceccarelli M, Fea AM. Minimally-invasive glaucoma surgeries (migs) for open angle glaucoma: a systematic review and metaanalysis. PLoS ONE. 2017;12:e0183142.

121. Pillunat $L E$, Erb C, Junemann AG, Kimmich F. Micro-invasive glaucoma surgery (Migs): a review of surgical procedures using stents. Clinical ophthalmology (Auckland, NZ). 2017;11:1583-600.

122. Chen DZ, Sng CCA. Safety and efficacy of microinvasive glaucoma surgery. J Ophthalmol. 2017;2017:3182935.

123. Lichter PR, Musch DC, Gillespie BW, Guire KE, Janz NK, Wren PA, et al. Interim clinical outcomes in the collaborative initial glaucoma treatment study comparing initial treatment randomized to medications or surgery. Ophthalmology 2001;108:1943-53.

124. Migdal C, Gregory W, Hitchings R. Long-term functional outcome after early surgery compared with laser and medicine in open-angle glaucoma. Ophthalmology 1994;101:1651-6. discussion 7

125. Jones L, Downie LE, Korb D, Benitez-Del-Castillo JM, Dana R, Deng SX, et al. Tfos dews li management and therapy report. Ocul Surf. 2017;15:575-628.

126. Trivedi A, Katelaris C. Presentation, diagnosis, and the role of subcutaneous and sublingual immunotherapy in the management of ocular allergy. Clin Exp Optom. 2020 (epub ahead of print).

127. Hsu KH, Gupta K, Nayaka H, Donthi A, Kaul S, Chauhan A. Multidose preservative free eyedrops by selective removal of benzalkonium chloride from ocular formulations. Pharm Res. 2017;34:2862-72.

128. Hsu KH, Chauhan A. Rapid and selective removal of preservative from ophthalmic formulations during eyedrops instillation. Eur J Pharm Biopharm. 2015;97:30-8.
129. Nagai N, Yoshioka C, Tanino T, Ito Y, Okamoto N, Shimomura Y. Decrease in corneal damage due to benzalkonium chloride by the addition of mannitol into timolol maleate eye drops. J Oleo Sci. 2015;64:743-50.

130. Stanton D, Batich C, Schultz G, Gibson D, Guidi C, Yang Q, et al. A novel method to eliminate preservatives in eye drops. J Ocul Pharm Ther. 2018;34:584-9.

\section{ACKNOWLEDGEMENTS}

Editorial assistance in the preparation of this article was provided by Tony Realini, MD, MPH of Hypotony Holdings LLC. Support for this assistance was provided by Ocular Therapeutix, Inc. Open access fees, and other support for this review was funded by Ocular Therapeutix, Inc.

\section{AUTHOR CONTRIBUTIONS}

All authors certify that they have participated sufficiently in the conception, design, and writing of this manuscript.

\section{COMPETING INTERESTS}

MHG, SV, FQS, NB, and $\pi$ receive compensation from and have financial holdings in Ocular Therapeutix, Inc. as employees of the company.

\section{ADDITIONAL INFORMATION}

Correspondence and requests for materials should be addressed to S.V.

Reprints and permission information is available at http://www.nature.com/ reprints

Publisher's note Springer Nature remains neutral with regard to jurisdictional claims in published maps and institutional affiliations.

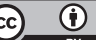

Open Access This article is licensed under a Creative Commons Attribution 4.0 International License, which permits use, sharing, adaptation, distribution and reproduction in any medium or format, as long as you give appropriate credit to the original author(s) and the source, provide a link to the Creative Commons license, and indicate if changes were made. The images or other third party material in this article are included in the article's Creative Commons license, unless indicated otherwise in a credit line to the material. If material is not included in the article's Creative Commons license and your intended use is not permitted by statutory regulation or exceeds the permitted use, you will need to obtain permission directly from the copyright holder. To view a copy of this license, visit http://creativecommons. org/licenses/by/4.0/

(c) The Author(s) 2021 